\title{
The Changes of Serum Angiotensin-Converting Enzyme 2 in Patients with Pulmonary Arterial Hypertension due to Congenital Heart Disease
}

\author{
Hai-long Daia, b Yue Guo ${ }^{a} \quad$ Xue-feng Guang ${ }^{a}$ Zhi-cheng Xiao ${ }^{\text {b, c }}$ \\ Ming Zhang ${ }^{b}$ Xiao-long Yin ${ }^{a}$ \\ a Department of Cardiology, Yan'an Affiliated Hospital of Kunming Medical University, Yunnan Cardiovascular \\ Hospital, and ${ }^{b}$ Institute of Molecular and Clinical Medicine, Kunming Medical University, Kunming, China; \\ 'Monash Immunology and Stem Cell Laboratories, Monash University, Melbourne, Vic., Australia
}

\section{Key Words}

Congenital heart disease $\cdot$ Pulmonary arterial hypertension . Angiotensin-converting enzyme 2

\begin{abstract}
Background: Angiotensin-converting enzyme 2 (ACE2), a primary component of the vasoprotective axis in the reninangiotensin system (RAS), has recently been found to have regulatory actions in hypoxic pulmonary hypertension and monocrotaline-induced pulmonary hypertension. We explored the hypothesis that the level of ACE2 protein contents may be decreased in patients with pulmonary arterial hypertension (PAH) due to congenital heart disease (CHD). Objective: We observed the serum ACE2 protein contents in patients with PAH due to CHD (CHD-PAH), and investigated their correlation with mean pulmonary arterial pressure (mPAP). Methods: One hundred and four patients with CHD and 33 normal control patients (group A) were involved in the research. The patients with CHD were divided into 55 cases of nonpulmonary hypertension (group B), 25 cases of mild to moderate pulmonary hypertension (group C) and 24 cases of severe pulmonary hypertension (group D). The serum level of ACE2 protein contents were detected by enzyme-linked immunosorbent assay (ELISA), and the relation-
\end{abstract}

ship between these contents and mPAP were analyzed. $\boldsymbol{R e}$ sults: ACE 2 protein contents significantly declined as mPAP increased. The MPAP was negatively correlated with the level of ACE2 protein contents. Conclusions: These results demonstrated that ACE2 may play an important regulatory role in CHD-PAH.

Copyright $\odot 2013$ S. Karger AG, Basel

\section{Introduction}

Pulmonary arterial hypertension $(\mathrm{PAH})$ is a progressive disease with poor survival outcome. It can be classified into 5 main categories according to the updated clinical classification. PAH due to congenital heart disease (CHD), i.e. CHD-PAH, with systemic-to-pulmonary shunt is a major subgroup [1]. The advanced stage of this is called Eisenmenger syndrome which forms a small percentage $(1 \%)$ of the CHD population [2]. Eisenmenger syndrome is characterized by reversed right-to-left intracardiac shunting of blood and significant hypoxemia. Patients with Eisenmenger syndrome have a progressive

H.D., Y.G. and X.G. contributed equally to the work.

\section{KARGER}

E-Mail karger@karger.com

www.karger.com/crd
(C) 2013 S. Karger AG, Basel

$0008-6312 / 13 / 1244-0208 \$ 38.00 / 0$
Dr. Xiao-long Yin

Department of Cardiology, Yan'an Affiliated Hospital of Kunming Medical University Yunnan Cardiovascular Hospital

Kunming, Yunnan 650051 (China)

E-Mail yinx1001@gmail.com 
poor exercise capacity, a reduced life expectancy and heart failure can occur. The exact pathogenesis of CHD$\mathrm{PAH}$ is poorly understood. Therapeutic options for patients are limited.

Angiotensin-converting enzyme 2 (ACE2), a homolog of ACE, is a carboxypeptidase that degrades angiotensin (Ang) II to Ang-(1-7) [3, 4]. ACE2 plays an important role in the vasoprotective axis (ACE2-Ang-(1-7)-Mas axis) of the renin angiotensin system (RAS) and counterbalances the vasoconstrictive, proliferative and fibrotic axes [ACE-Ang II-Ang II type 1 receptor (AT1R) axis] of the RAS [5-7]. ACE2 is highly expressed in the lungs, is present in the circulation and is an integral membrane protein in 72 organs [8]. Recent studies demonstrated the therapeutic effects of ACE2 activation by a synthetic molecule [6], the continuous injection of resorcinolnaphthalein [9] or ACE2 gene transfer $[10,11]$ in a monocrotaline-induced PAH model. Recombinant ACE2 blunts the rise in pulmonary arterial pressure (PAP) that occurs in response to acute hypoxia [12]. Recombinant ACE2 attenuates arterial hypoxemia, pulmonary hypertension and the redistribution of pulmonary blood flow in a lipopolysaccharide-induced lung injury model [13]. The expression of Ang II was increased in a left-to-right, shuntinduced PAH model [14]. These observations led us to hypothesize that the imbalance between the ACE2-Ang(1-7)-Mas axis and the ACE-Ang II-AT1R axis could participate in the pathogenesis of CHD-PAH, the serum level of ACE2 protein contents may be decreased in patients with CHD-PAH.

\section{Materials and Methods}

Study Population and Design

This study was conducted in the Department of Cardiology of the Yan'an Affiliated Hospital of Kunming Medical University between April and August 2011.

Requirements for enrollment included: an established diagnosis of isolated atrial or ventricular septal defect using the echocardiogram and an age of $>14$ years. Exclusion criteria included: (1) coronary artery disease, (2) hypertension, (3) heart valve diseases, (4) diabetes mellitus, (5) autoimmune diseases, (6) bleeding tendency, (7) liver or renal insufficiency, (8) pulmonary disease (e.g. chronic obstructive pulmonary disease and pulmonary embolism), (9) HIV infection and (10) refusal to participate in the study.

The CHD patients were assigned to 3 groups according to mean PAP (mPAP) which was measured by right-heart catheterization [1]: CHD with nonpulmonary hypertension ( $\mathrm{mPAP} \leq 25 \mathrm{~mm} \mathrm{Hg}$ ), CHD with mild to moderate pulmonary hypertension $(50 \mathrm{~mm} \mathrm{Hg}$ $\geq \mathrm{mPAP}>25 \mathrm{~mm} \mathrm{Hg}$ ) and $\mathrm{CHD}$ with severe pulmonary hypertension ( $\mathrm{mPAP}>50 \mathrm{~mm} \mathrm{Hg}$ ). The ethics committee of our hospital approved this study, and written informed consent was obtained from all patients and control subjects.
Serum Samples Collection and Measurements

We collected 4-ml blood samples in glass tubes without additive and allowed them to clot at room temperature for $60 \mathrm{~min}$. Serum was separated by centrifugation at 3,000 rpm for $15 \mathrm{~min}$. Serum aliquots of $1.50 \mathrm{ml}$ were obtained and stored at $-80^{\circ} \mathrm{C}$ until use. The plasma ACE2 protein contents were measured using a commercially available enzyme-linked immunosorbent assay (ELISA) kit (R\&D Systems, Shanghai Genmed Scientifics Inc., China). All steps were performed according to the instruction.

Fasting blood samples were analyzed for kidney function, total cholesterol (TC), triglyceride (TG) and liver function (e.g. alanine aminotransferase and aspartate aminotransferase) in a routine diagnostic analyzer.

\section{Hemodynamic Measurements}

All patients were hospitalized and all provided written informed consents. Right-heart catheterization was performed in the catheterization lab. With local anesthesia under continuous electrocardiographic monitoring, a 6-French pigtail catheter was advanced into the pulmonary artery through the right femoral vein by placement of a 6- or 7-French vascular sheath. The catheter was flushed with heparinized normal saline. Correct catheter positioning was verified by fluoroscopy. Transducers were positioned at the midaxillary line and zeroed at the atmospheric pressure. The patients were equilibrated for about $10 \mathrm{~min}$ before PAP measurements were taken.

\section{Statistical Analysis}

Data were analyzed using SPSS 17.0 software (SPSS, Chicago, Ill., USA). All data are presented as mean \pm standard deviation (SD). Proportions were compared using the $\chi^{2}$ test, continuous Gaussian distributed variables with ANOVA and non-Gaussian distributed variables with the Kruskal-Wallis test. The relationship between ACE2 protein contents and MPAP was assessed by the Spearman rank correlation. Statistical significance was set at $\mathrm{p}<$ 0.05 .

\section{Results}

\section{Clinical Characteristics of Participants}

The study included 104 CHD patients (35 men and 69 women; 73 atrial septal defect, 31 ventricular septal defect) and 33 normal controls (group A). The $104 \mathrm{CHD}$ patients were assigned to 3 groups: 55 cases of CHD with nonpulmonary hypertension (group $\mathrm{B}, \mathrm{mPAP} \leq 25 \mathrm{~mm}$ $\mathrm{Hg}$ ), 25 cases of $\mathrm{CHD}$ with mild to moderate pulmonary hypertension (group C, $50 \mathrm{~mm} \mathrm{Hg} \geq \mathrm{mPAP}>25 \mathrm{~mm} \mathrm{Hg}$ ) and 24 cases of $\mathrm{CHD}$ with severe pulmonary hypertension (group D, mPAP >50 mm Hg). Demographic and general clinical features are presented in table 1 . There were no significant differences in sex, age, alanine and aspartate aminotransferase, creatinine, TC and TG between groups. 


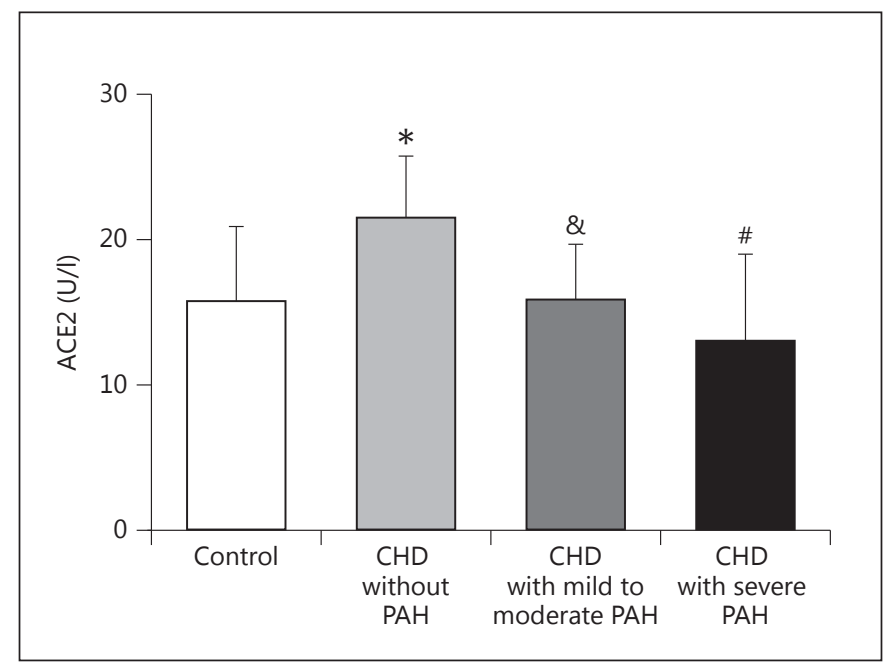

Fig. 1. The level of ACE2 protein contents in the study population. ${ }^{*} \mathrm{p}<0.001$ vs. group $\mathrm{A} ;{ }^{\&} \mathrm{p}<0.001$ vs. group $\mathrm{B} ;{ }^{*} \mathrm{p}<0.001$ vs. group $\mathrm{C}$.

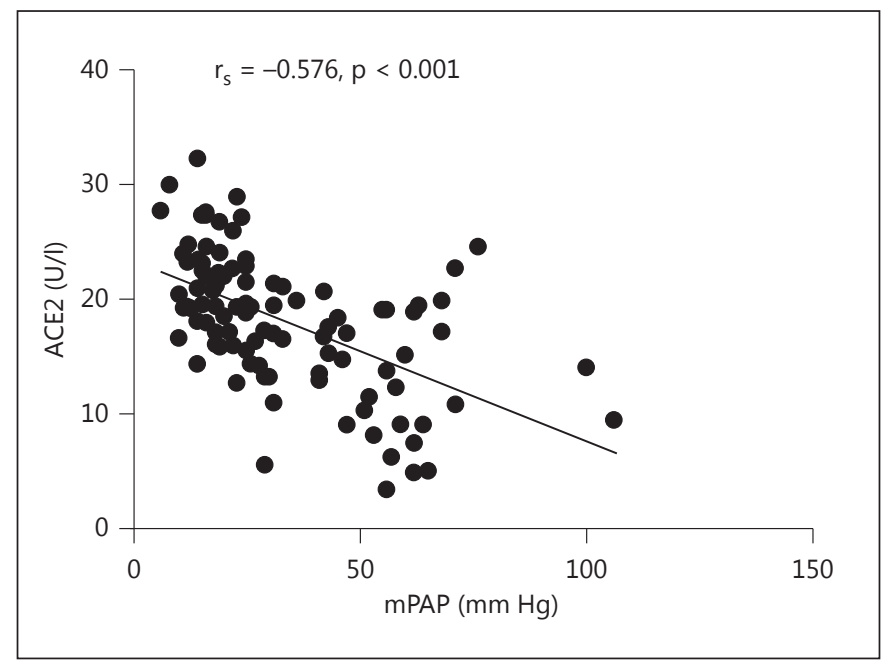

Fig. 2. ACE2 protein contents correlated to mPAP.

Table 1. Clinical characteristics of the study groups

\begin{tabular}{lcccc}
\hline Characteristics & $\begin{array}{l}\text { Control } \\
(\mathrm{n}=33)\end{array}$ & $\begin{array}{l}\text { CHD without PAH } \\
(\mathrm{n}=55)\end{array}$ & $\begin{array}{l}\text { CHD with mild to } \\
\text { moderate PAH } \\
(\mathrm{n}=25)\end{array}$ & $\begin{array}{l}\text { CHD with severe PAH } \\
(\mathrm{n}=24)\end{array}$ \\
\hline Male gender & $17(51.5)$ & $17(30.9)$ & $6(24)$ & $12(50)$ \\
Age, years & $41.39 \pm 12.64$ & $34.64 \pm 16.72$ & $43.41 \pm 18.61$ & $33.90 \pm 17.02$ \\
Patients with atrial septal defect & - & $47(85.5)$ & $18(72)$ & $8(33.3)^{*}$ \\
Patients with ventricular septal defect & - & $8(14.5)$ & $7(28)$ & $16(66.7)^{*}$ \\
mPAP, mm Hg & - & $17.65 \pm 4.80^{\#}$ & $35.48 \pm 7.30^{\#}$ & $64.62 \pm 13.47^{\#}$ \\
Alanine aminotransferase, U/l & $28.6 \pm 7.69$ & $29.9 \pm 5.93$ & $32.4 \pm 6.13$ & $34.7 \pm 8.32$ \\
Aspartate aminotransferase, U/l & $29.9 \pm 6.93$ & $31.5 \pm 6.47$ & $32.1 \pm 6.04$ & $30.2 \pm 7.01$ \\
Creatinine, $\mu$ mol/l & $68 \pm 14$ & $73 \pm 8$ & $66 \pm 14$ & $70 \pm 12$ \\
TC, mmol/l & $4.82 \pm 0.70$ & $5.01 \pm 0.85$ & $4.68 \pm 0.89$ & $4.43 \pm 0.84$ \\
TG, mmol/l & $1.12 \pm 0.15$ & $0.98 \pm 0.79$ & $1.21 \pm 0.37$ & $1.07 \pm 0.46$ \\
\hline
\end{tabular}

Data are means \pm SD or absolute numbers with percentages in parentheses.

${ }^{*} \mathrm{p}<0.01$ vs. CHD without PAH and CHD with mild to moderate PAH groups; ${ }^{*} \mathrm{p}<0.001$ vs. CHD without PAH, CHD with mild to moderate $\mathrm{PAH}$ and $\mathrm{CHD}$ with severe $\mathrm{PAH}$ groups. All other comparisons between the control and the other 3 groups were insignificant.

The Level of ACE2 Protein Contents in the Study

Population

The ACE2 protein contents in plasma measured by ELISA were $15.79 \pm 5.03 \mathrm{U} / \mathrm{l}, 21.49 \pm 4.19 \mathrm{U} / \mathrm{l}, 15.84 \pm 3.80$ $\mathrm{U} / \mathrm{l}$ and $12.96 \pm 5.98 \mathrm{U} / \mathrm{l}$ in groups $\mathrm{A}, \mathrm{B}, \mathrm{C}$ and $\mathrm{D}$, respectively. The level of ACE2 protein contents in group $\mathrm{B}$ was significantly higher than in group A $(\mathrm{p}<0.001)$, the level in groups $\mathrm{C}$ and $\mathrm{D}$ was significantly lower than in group
$B(p<0.001)$ and the level in group D was significantly lower than in groups $A$ and $C(p<0.05)$. There was no significant difference between the level in group $\mathrm{A}$ and in group C ( $p>0.05)$ (fig. 1).

Through correlation and regression analysis, there was a negative correlation between $\mathrm{mPAP}$ and ACE2 protein contents $(\mathrm{r}=-0.576, \mathrm{p}<0.001)$ (fig. 2$)$. 


\section{Discussion}

$\mathrm{CHD}$ is the most common of major congenital malformations. Blood initially shunts from the systemic to the pulmonary circulation because the resistance in the former is higher, and a large defect and chronic shunting induce PAH. Progressive increase in pulmonary vascular resistance is characterized by vascular wall remodeling with intimal fibrosis, increased medial thickness and plexiform lesions [15] which finally lead to Eisenmenger syndrome. The pathophysiological mechanisms responsible for the development of CHD-PAH are not completely known. Pulmonary vascular injury, inflammatory reaction and endothelial dysfunction [16] may all play an important role in this condition.

It has been proposed that an activated RAS causes an imbalance between the vasoconstrictive (ACE-Ang IIAT1R axis) and vasodilator (ACE2-Ang-(1-7)-Mas axis) mechanisms involving the pulmonary circulation leading to the development of PAH. ACE inhibitors and AT1R blockers can inhibit the ACE-Ang II-AT1R axis, but their primary effects are to reduce systemic blood pressure, thus they are unsuccessful in treating patients with PAH as these patients are already at a high risk of developing hypotension due to right-ventricular overload [17]. ACE2 is expressed in endothelial cells, especially in the lung microvascular endothelial cells $[18,19]$. Some studies $[6,10$, 11] have shown that ACE2 overexpression or activation induce a beneficial pulmonary outcome with no adverse effects on systemic blood pressure.

The major finding of this study is that the level of ACE2 protein contents in CHD patients with nonpulmonary hypertension was significantly higher than in the group of normal controls and the level in CHD patients with pulmonary hypertension was significantly lower than in CHD patients with nonpulmonary hypertension. This phenomenon may be due to ACE2 being increased in CHD patients before the onset of PAH in order to prevent the development of PAH. However, along with the progressive endothelial damage, the expression of ACE2 was decreased.

In summary, this study is the first to demonstrate that the serum level of ACE2 protein contents is decreased in patients with CHD-PAH. We speculate that the decrease in ACE2 and the increased in Ang II shift the balance of the RAS towards the ACE-Ang II-AT1R axis, resulting in increases in vascular remodeling, fibrosis and $\mathrm{PAH}$ in CHD patients. So ACE2 may be a target for the treatment of CHD-PAH. Further studies are necessary to substantiate this conclusion.

\section{Acknowledgement}

This study was supported by the grants form the Key Project of Yunnan Natural Scientific Fund (2012FB009).

\section{References}

1 Simonneau G, Robbins IM, Beghetti M, Channick RN, Delcroix M, Denton CP, Elliott CG, Gaine SP, Gladwin MT, Jing ZC, Krowka MJ, Langleben D, Nakanishi N, Souza R: Updated clinical classification of pulmonary hypertension. J Am Coll Cardiol 2009;54(1 suppl):S43-S54

2 Trojnarska O, Plaskota K: Therapeutic methods used in patients with Eisenmenger syndrome. Cardiol J 2009;16:500-506.

-3 Vaz-Silva I, Carneiro MM, Ferreria MC, Pinheiro SV, Silva DA, Silva-Fillo AL, Witz CA, Reis AM, Santos RA, Reis FM: The vasoactive peptide angiotensin-(1-7), its receptor Mas and the angiotensin-converting enzyme type 2 are expressed in the human endothelium. Reprod Sci 2009;16:247-256.

4 Imai Y, Kuba K, Ohto-Nakanishi T, Penninger JM: Angiotensin-converting enzyme 2 (ACE2) in disease pathogenesis. Circ J 2010; 74:405-410.
5 Raizada MK, Ferreira AJ: ACE2: a new target for cardiovascular disease therapeutics. J Cardiovasc Pharmacol 2007;50:112-119.

-6 Ferreira AJ, Shenoy V, Yamazato Y, Sriramula S, Francis J, Yuan L, Castellano RK, Ostrov DA, Oh SP, Katovich MJ, Raizada MK: Evidence for angiotensin-converting enzyme 2 as a therapeutic target for the prevention of pulmonary hypertension. Am J Respir Crit Care Med 2009;179:1048-1054.

7 Shenoy V, Qi Y, Katovich MJ, Raizada MK: ACE2, a promising therapeutic target for pulmonary hypertension. Curr Opin Pharmacol 2011;11:150-155.

8 Johnson JA, West J, Maynard KB, Hemnes AR: ACE2 improves right ventricular function in a pressure overload model. PLoS One 2011;6:e20828.
9 Li G, Xu YL, Ling F, Liu AJ, Wang D, Wang Q, Liu YL: Angiotensin-converting enzyme 2 activation protects against pulmonary arterial hypertension through improving early endothelial function and mediating cytokines levels. Chin Med J (Engl) 2012;125:1381-1388.

10 Yamazato Y, Ferreira AJ, Hong KH, Sriramula S, Francis J, Yamazato M, Yuan L, Bradford CN, Shenoy V, Oh SP, Katovich MJ, Raizada MK: Prevention of pulmonary hypertension by angiotensin-converting enzyme 2 gene transfer. Hypertension 2009;54:365-371.

-11 Shenoy V, Ferreira AJ, Qi Y, Fraga-Silva RA, Díez-Freire C, Dooies A, Jun JY, Sriramula S, Mariappan N, Pourang D, Venugopal CS, Francis J, Reudelhuber T, Santos RA, Patel JM, Raizada MK, Katovich MJ: The ACE2/ Ang-(1-7)/Mas axis confers cardiopulmonary protection against lung fibrosis and pulmonary hypertension. Am J Respir Crit Care Med 2010;182:1065-1072. 
12 Kleinsasser A, Pircher I, Treml B, Schwienbacher M, Schuster M, Janzek E, Loibner H, Penninger JM, Loeckinger A: Recombinant angiotensin-converting enzyme 2 suppresses pulmonary vasoconstriction in acute hypoxia. Wilderness Environ Med 2012;23:24-30.

$\rightarrow 13$ Treml B, Neu N, Kleinsasser A, Gritsch C, Finsterwalder T, Geiger R, Schuster M, Janzek E, Loibner H, Penninger J, Loeckinger A: Recombinant angiotensin-converting enzyme 2 improves pulmonary blood flow and oxygenation in lipopolysaccharide induced lung injury in piglets. Crit Care Med 2010;38:596601.
14 Rondelet B, Kerbaul F, Van Beneden R, Hubloue I, Huez S, Fesler P, Remmelink M, Brimioulle S, Salmon I, Naeije R: Prevention of pulmonary vascular remodeling and of decreased BMPR-2 expression by losartan therapy in shunt-induced pulmonary hypertension. Am J Physiol Heart Circ Physiol 2005; 289:H2319-H2324.

15 Farber HW, Loscalzo J: Pulmonary arterial hypertension. N Engl J Med 2004;351:16551665.

16 Smadja DM, Gaussem P, Mauge L, Israel-Biet D, Dignat-George F, Peyrard S, Agnoletti G, Vouhe PR, Bonnet D, Levy M: Circulating endothelial cells: a newcandidate biomarker of irreversible pulmonary hypertension secondary to congenital heart disease. Circulation 2009;119:374-381.
7 Schrier RW, Bansal S: Pulmonary hypertension, right ventricular failure, and kidney: different from left ventricular failure? Clin J Am Soc Nephrol 2008;3:1232-1237.

18 Hayashi N, Yamamoto K, Ohishi M, Tatara Y, Takeya Y, Shiota A, Oguro R, Iwamoto Y, Takeda M, Rakugi H: The counterregulating role of ACE2 and ACE2-mediated angiotensin 1-7 signaling against angiotensin II stimulation in vascular cells. Hypertens Res 2010; 33:1182-1185.

19 Li J, Gao J, Xu YP, Zhou TL, Jin YY, Lou JN: Expression of severe acute respiratory syndrome coronavirus receptors, ACE2 and CD209L in different organ derived microvascular endothelial cells. Zhonghua Yi Xue Za Zhi 2007;87:833-837. 